\title{
The Development and Application of Charitable Trust in China
}

\section{Youyou Cui}

Central University of Finance and Economics, Beijing 100081, China

\begin{abstract}
Charitable trust is a combination of charity and trust industry. The development of charitable trust started earlier in foreign countries and has been widely used. Charitable trust in China is still in its infancy, lacking legal support and a complete operation system. Problems such as unclear boundaries and imperfect tax preference system has occurred, and a complete public trust system has not yet been formed. But from a long perspective, charitable trust has a high application value and prospects in China's poverty alleviation, pension and other fields. In this paper, the development status of charitable trust in China is summarized and analyzed.
\end{abstract}

Key words: Charitable trust; Development status; Tax preference

Publication date: April, 2021; Publication online: 30 April, 2021

*Corresponding author: Youyou Cui, 327481963@qq.com

\section{Introduction}

\subsection{Concept of charitable trust}

Charitable trusts are also called "public trusts". A trust whose purpose is only to realize social charity and whose beneficiary is the whole society or part of the general public. Trust is not only a special property management system and legal behavior, but also a financial system, a part of the modern financial system. Trust is an act that the trustee entrusts the property to the trustee and gives the right to use the property to the trustee on the basis of trust, and the trustee manages or disposes of the property in his own name for the benefit of the beneficiary or for specific purposes. The function of trust is summed up as "being entrusted by others and following others' advice to manage money for others".

Charitable trusts are established for the purpose of public welfare. The beneficiaries of charitable trusts are all members of the society. Charitable trusts are diversified and have no clear indication and regulations. The rules of equity generally divide charitable trusts into four categories: those that relieve the poor, those that promote education, those that promote religion, and those that benefit society Charitable trusts are also known as public trusts. There is no difference between the two in countries such as the United Kingdom and the United States in terms of laws and relevant regulations. Therefore, they are regarded as the same in academic terms. The business process of a charitable trust includes application for establishment of a charitable trust, transfer of trust assets, management and use of trust property, trust supervision and trust termination.

\subsection{Characteristics of charitable trusts}

In Western countries, the development of charitable trusts can be roughly divided into three stages: classical charitable trusts, growth leaps and development matures. Charitable trust appeared early in Western countries, especially in the United Kingdom and the United States. As early as the 17th century, the United Kingdom issued relevant laws and regulations, so charitable trust has become a relatively perfect financial product in Western countries. As for how to define whether a trust is a charitable trust, the legal provisions are to measure whether it is set up for the purpose of charity. Charity is the most core element of charitable trust.

The purpose of the charitable trust has absoluteness, according to the relevant stipulations, the purpose of the client set up a trust there is no single orientation, for a charitable trust, is dedicated to public welfare, the purpose of all its one if there is an exception to the trust cannot be charitable trust and enjoy the corresponding preferential tax. Such strict requirements are to prevent people from doing 
private things under the guise of public welfare. Charitable trusts are established to serve the whole society, thus ensuring the development of charitable trusts.

The assets of charitable trusts are independent. After I intend to set up a charitable trust after principal basis, the disposition of property of the principal is shifted. In the process of the use of the trust fund, the client can't casually disposal of property, and has commissioned the property and the fixed assets of the principal and self-owned assets phase separation, mutual influence and interference. In the process of the trustee's disposal of the trust property, provided that the trustee does not violate the relevant legal provisions, if there is any loss of the trust property, the loss shall not be borne by the trustee but by his own trust.

Property independence is one of the important characteristics, ensuring the security of property, reducing the economic risk in the process of operation.

Another characteristic of charitable trusts is the use of the principle of approximation for public welfare purposes.

After charitable trusts are established legally, due to the continuous development of society and the emergence of social problems, the original purpose of charitable trusts will change due to the some certain social problems or the amendment of laws and changes in the legal system. When such changes occur, the principle of approximation enable charitable trusts to continue to operate. This is the most important difference between charitable trusts and other general trusts. If the original purpose of the charitable trust cannot be achieved in the process, and the goal is transferred within charity, it will still be valid, the purpose of which will be changed to a similar purpose in order to keep that charitable long term, sustainable and promising. There are still some ambiguities and deficiencies in the principle of approximation in China. In the development of charitable trusts, we can further learn from the experiences of the United States and the United Kingdom, which have relatively complete legal provisions, and develop charitable trusts with local characteristics in China ${ }^{[1]}$.

Charitable trusts do not designate beneficiaries. The beneficiaries of a charitable trust are not specified in a certain category, but belong to the whole public. When determining the beneficiaries of charitable trusts, it is necessary to take whether they meet the social public interest as the standard, rather than the status and number of beneficiaries as the screening standard. There can be no "private connection point" between the principal and the beneficiary. However, in the actual operation of charitable trusts, the definitions of private connection points and social public interests need careful consideration and rational understanding of social public interests.

\section{The development status of charitable trusts in China}

Chapter VI of the Trust Law issued in 2001 contains 15 provisions on the definition, establishment, use of property, establishment of supervisors, operation reports, supervision and termination of charitable trusts, including: (1) The purpose of the establishment of public trust is to meet the needs of charity and serve the social public groups; (2) The trust property and its income can only be used for the purpose of public welfare, and cannot be used to meet the needs of individuals; (3) To be established upon the examination and approval of the regulatory agency of public undertakings; (4) Charitable trusts need to set up a corresponding supervision system and special supervisors to supervise and regulate them, etc. In China, charitable trust has higher application value and better development prospects. Charitable trusts can improve the ability to preserve property, enhance the independence of property, and are applicable to preferential tax policies ${ }^{[2]}$. In 2018, China's charitable trust industry saw a significant increase in the number of charitable trusts, and continued at a fast growth rate ${ }^{[3]}$. The newly established trust property reached 1.201 billion yuan, an increase by $84.42 \%$ compared with 2017. In 2019, the number of provinces and cities in China that have registered for charitable trusts reached 23, meanwhile, Yunnan province completed filing for the first charitable trust with "dual trustees". At present, there are obvious regional differences in development of charitable trusts. The filing systems of charitable trusts are concentrated in developed regions and regions badly to be lifted out from poverty.

From the perspective of the main mode of charitable trust development in our country, there are mainly standard mode of charitable trust, "charitable trust + charity" mode, "charity + charitable trust" mode, "public welfare purpose trust + charity" mode, "family trust + charitable trust" mode, "non-cash assets + charitable trust charity organization" mode, etc ${ }^{[4]}$.

In terms of the characteristics of the development of charitable trusts in China, the first is that the development of charitable trusts still has short-term effects, which are mostly driven by specific task-oriented projects, such as poverty 
alleviation, assistance and other projects that need short-term results. Secondly, the development varies from local economic development and characteristics. In developed areas, charitable trusts are in a large number and are well operated, while in underdeveloped areas, the situation is quite different. Thirdly, the trustee models of trust companies continue to heat up. Fourthly, the source of trust property is more extensive, and presents the characteristics of dynamic and pluralistic. Fifthly, innovative poverty alleviation models have appeared frequently, such as "poverty alleviation by industry + targeted assistance" and "charitable trust + corporate loans".

At the same time, there are still some issues and limitations with the development of charitable trusts in China, such as unclear tax preferential policies, single source of trust property, short of supervision, rigid principle of complete public welfare for charitable purposes, and the too little supporting to the development of charitable trusts from the Charity Law ${ }^{[5]}$.

\section{Charitable trust tax and legal issues in China}

\subsection{The status quo of tax preference system for charitable trusts in China}

From the perspective of the motives of donation to charitable causes, it can be roughly divided into two categories $^{[6]}$. One is the traditional virtue of voluntary help with the poor, which is a kind of altruism and does not seek returns. The other is a self-interested motive to improve the reputation by means of donation or obtain a sense of social recognition or as well as certain honor or support preferential treatment. Whether from the perspective of self-interest or altruism, support from certain tax policies and legal policies can enhance this kind of donation to a certain extent, which is conducive to the development of charity, and promotes the mutual benefits between charity donors and beneficiaries.

The tax preference system of charitable trust mainly includes the content, object and management system of the tax preference of charitable trust.

In The Theory of Modern Trust Law, it was first proposed that charitable trust plays a key role in charitable causes and is an important model and method to achieve charitable purposes ${ }^{[7]}$. The tax preferences enjoyed by China's philanthropic subjects can be classified into three categories, namely, the preferences of donors, charitable organizations themselves and beneficiaries ${ }^{[8]}$.

At present, the tax preference system of charitable trust in China is not perfect, and laws related to charitable industry in China are still insufficient in quantity.

In terms of the tax policy of charitable trusts, other laws need to be used for reference, which hinders the development of charitable trusts to some extent. The preferential tax system of charitable trust in China has different provisions according to the trustees of charitable trusts. When charitable public welfare organizations or foundations act as trustees of charitable trusts, they can enjoy corporate income tax, value-added tax, property tax and other preferential policies. The Charity Act provides that both charitable organizations and trust companies can become beneficiaries of charitable trusts (the Charity Act). According to the provisions of the Charity Law, charitable organizations as trustees can enjoy tax advantages in the operation and flow of property, but trust companies, as for-profit organizations, do not enjoy tax advantages when they act as trustees. While in the process of actual operation and development of the charitable trust has related regulation and file charitable trust can obtain certain tax and preferential policy support, but the policy and system in the subsequent development of charitable trust has not really been implemented, also has not issued a formal legal norms, the charitable trust in their daily use of capital and business processing can't enjoy the corresponding preferential tax policies.

\subsection{The preferential system of charitable trust in China is insufficient}

Charitable trust has the unique function and specific, in the process of development of continuous innovation out a variety of patterns, in an important position in China's charity, but the development of charitable trust in China compared with western developed countries, there are some shortcomings and limitations, the charitable trust in China than in other countries such as Britain and the United States, and other countries, started late, and development is slow, for the 1601 charity for reasons of law in Britain charitable trusts have relevant regulation and system, and the charitable trust in China in the 20th century began to produce and slow development. Charitable trusts in China lack an independent tax preference legal system.

Charitable trust started late in China, and compared with other financial products, it has its particularity and uniqueness. In the actual operation of charitable trusts, existing laws and regulations need to be used for reference. In the process of social and economic development, new 
social problems and new situations are constantly emerging, and the original laws are gradually unable to meet the needs of economic and social development.

At present, the tax incentives of charitable trusts in China are relatively small. Although the relevant laws stipulate that charitable trusts can enjoy tax incentives, there are no specific provisions on the preferential policies of charitable trusts, and there is no clear explanation on the conditions and practices for enjoying tax incentives. The other has not yet formulated specifically for the trust tax system in our country, due to the trust the trustor, trustee and beneficiary tripartite main body and property transfer twice, although the charity do not need to collect taxes, but if it is equity and housing property, such as regards to the transfer request, according to the existing transfer tax system will lead to double taxation problem in the two property transfer.

The Charity Law stipulates that the trust property and trust proceeds of public trust shall not be used for non-public purposes, and that part of trust property shall not be used for public welfare, and part of trust property shall not be used for non-public welfare public trust. However, in practice, it is often the case that the property and income of trust property are used for public welfare and non-public welfare.

\subsection{Suggestions of improving China's charitable trust tax system}

Improve the legal system of charitable trust tax preference in China.

At present, the relevant laws of charitable trusts in China are still lacking and inadequate to some extent, leading to the problems of inconsistent rights and responsibilities and unclear boundaries in the actual operation of charitable trusts in China, which to a large extent hinders the development speed of charitable trusts in China, and is prone to the problems of inequality and imbalance. It is necessary to provide a favorable legal environment for charitable trusts in China, establish a unified and sound legal norms, and standardize the preferential tax system for charitable trusts by legislation ${ }^{[9]}$.

To solve the problem of double taxation, double taxation increases the operating cost of charitable trusts, which is not conducive to the development of charitable trusts. It is necessary to establish a sound and perfect tax collection standard, and give appropriate preferential treatment and reduction to the charitable tax.

To strengthen the management of tax preferences for charitable trusts, it is necessary to pay attention to the standardization of legislation and management while improving the relevant laws and regulations of charitable trusts in China, so that the legal norms are highly standardized and operable ${ }^{[10]}$.

\section{Conclusion}

Charitable trust originated from other countries, such as the United Kingdom and the United States, and came to our country very late and developed slowly relatively in our county. The current charitable trust and charity career, has been playing a role in speeding the slow development since it was first introduced to China in 2018, and has entered the stage of rapid development and constantly improved its impact on China's poverty alleviation and pension etc.

However, there are still many deficiencies and limitations with China's charitable trusts, such as not yet forming a complete legal and regulatory system and unclear tax preference system.

The development of charitable trusts in China is still during the exploratory period, so we need to continue to learn from foreign experiences and develop charitable trusts with local characteristics in China.

\section{References}

[1] Lou QR. Understanding the "principle of similarity" in charitable trusts: American experience and China's reference $[\mathrm{J}]$. Journal of China University of Political Science and Law,2019(03):49-63+206-207.

[2] Wang L. The development status and application of charitable trust in China $[\mathrm{J}]$. Chinese and Foreign Entrepreneurs,2020(17):100.

[3] Xie ZM. The development status and application of charitable trust in China [J]. Market Forum,2019(06):43-45.

[4] Wang YG, Yang XD. Analysis on the development and business model of charitable trust in China $[\mathrm{J}]$. Southwest Finance, 2017 (05) :65-70.

[5] $\mathrm{Fu} \mathrm{CL}$, Wang MK.The current situation and policy suggestions of charitable trusts in China $[\mathrm{J}]$. Cooperative Economy and Science \& Technology,2020(09):50-53.

[6] Zhou B, Zhang KL. Corporate income tax policy for promoting charitable donations [J]. Tax Research, 2020 (5) : 49 - 55.

[7] Lai YH, Wang ZC, Modern Trust Law Theory [M]. Beijing: China University of Political Science and Law 
Press, 2002.

[8] Li YJ. Reasonable norms of tax policy in philanthropy legislation, in M. Zheng GC (Ed.), Research on Philanthropy Legislation, People's Publishing House, Beijing, 2015.
[9] Zhao LH.The tax policy of charitable trust [J].Tax Research, 2016 (8).

[10] Huang XY. On the legal system of charitable trust tax preferences in China $[\mathrm{J}]$. Economic and Social Development, 2018,16 (02): 13-18. 